\title{
Growth of proteinase-positive and proteinase- negative lactococci strains in reconstituted goat and cow milks
}

\author{
Daniel ST-GELAIS*, Sylvie HACHÉ \\ Agriculture and Agri-Food Canada, Food Research and Development Centre, \\ 3600 Casavant Boulevard West, Saint-Hyacinthe, Quebec J2S 8E3, Canada
}

Received 30 March 2006 - Accepted 16 August 2006

\begin{abstract}
The growth of proteinase-positive Lactococcus lactis strains and the proteinase-negative variants was studied in reconstituted goat and cow milks at 90,120 and $150 \mathrm{~g} \cdot \mathrm{kg}^{-1}$ total solids. pH change and lactic acid production were also compared in the two milks. Goat milk showed a higher buffering capacity than cow milk. The buffering capacity increased with the total solid contents in reconstituted milk. The proteinase-positive strains exhibited a higher maximum specific growth rate $\left(\mu_{\max }\right)$ and a higher acidification rate than the proteinase-negative variants. The bacterial count and the lactic acid concentration after $15 \mathrm{~h}$ of incubation were also higher with the proteinase-positive strains. The acidification rate and the lactic acid concentration after $15 \mathrm{~h}$ of incubation for all lactococci were significantly higher in reconstituted goat milk than in cow milk and increased with the total solid contents in reconstituted milk. The $\mu_{\max }$ and the viable counts obtained after $15 \mathrm{~h}$ of incubation for lactococci were relatively close in reconstituted goat and cow milks, with the exception of the $\mathrm{Wg} 2 \mathrm{~S}$ and $\mathrm{Wg} 2 \mathrm{~L}$ strains. For these strains, the $\mu_{\max }$ values were significantly higher in goat milk, but their bacterial counts after $15 \mathrm{~h}$ of incubation were lower in goat milk. An uncoupling was observed for these strains in goat milk. In general, reconstituted goat milk was an appropriate medium for the production of mesophilic lactic starters. However, to prevent an uncoupling with some strains such as the $\mathrm{Wg} 2 \mathrm{~S}$ and $\mathrm{Wg} 2 \mathrm{~L}$ strains, incubation in reconstituted goat milk at $21^{\circ} \mathrm{C}$ should be shorter than incubation in reconstituted cow milk.
\end{abstract}

goat milk powder / cow milk powder / growth of lactococci / reconstituted milk / proteinasenegative variants

摘要 - 蛋白酶阳性乳球菌和蛋白酶阴性变异体菌株在还原山羊奶和牛奶中的生长特性。本 文研究了蛋白酶阳性乳球菌 (Lactococcus lactis) 蛋白酶阴性变异体在总固性物含量分别为 90,120 和 $150 \mathrm{~g} \cdot \mathrm{kg}^{-1}$ 的还原羊奶和牛奶中生长特性。对菌株在两种还原奶中的产乳酸能力 和还原乳 $\mathrm{pH}$ 变化进行了比较。试验结果表明, 山羊奶对酸的缓冲能力高于牛奶, 而且缓 冲能力随着还原奶中总固性物含量的增加而提高。所有蛋白酶阳性乳球菌的最大比生长速 率 $\left(\mu_{\max }\right)$ 和产酸速率均高于蛋白酶阴性变异体。培养 $15 \mathrm{~h}$ 后, 蛋白酶阳性乳球菌在还原奶 中的细菌总数和乳酸浓度均高于蛋白酶阴性变异体; 所有菌株在还原山羊奶中的产酸速率 和乳酸浓度显著地高于在还原牛奶中, 并且这些指标随着还原奶中总固性物含量的增加而 提高。所有菌株在还原山羊奶和还原牛奶中培养 $15 \mathrm{~h}$ 后, 除了蛋白酶阳性乳球菌 $\mathrm{Wg} 2 \mathrm{~S}(\mathrm{~L}$. lactis ssp. cremoris) 和其蛋白酶阴性变异体 Wg2L 外, 其他菌株的 $\mu_{\mathrm{m}}$ 值和菌落总数非常相 近。这些菌株共同的特点是在还原山羊奶中 $\mu_{\max }$ 值高于还原牛奶, 但是在还原山羊奶中的

\footnotetext{
* Corresponding author (通讯作者): stgelaisd@agr.gc.ca
} 
细菌总数则低于还原牛奶。这些菌株在还原山羊奶中发生了解偶联现象。一般来讲, 还原 山羊奶适合嗜热乳酸菌的生长。然而为了防止一些菌株如 Wg2S 和 Wg2L 发生解偶联, 建 议这些菌株在 $21^{\circ} \mathrm{C}$ 山羊奶中的培养时间应该少于在还原牛乳中的培养时间。

\author{
山羊奶粉 / 牛奶粉 / 乳球菌的生长 / 还原奶 / 蛋白酶阴性变异体
}

Résumé - Croissance de lactocoques de souches protéinase-positive et protéinase-négative dans du lait de chèvre et de vache réhydraté. La croissance de souches protéolytiques de Lactococcus lactis et leurs variants non protéolytiques a été étudiée dans les laits de chèvre et de vache reconstitués à 90,120 et $150 \mathrm{~g} \cdot \mathrm{kg}^{-1}$ d'extrait sec. L'évolution du $\mathrm{pH}$ et la production d'acide lactique dans les deux laits ont également été comparées. Le lait de chèvre avait un pouvoir tampon plus élevé que le lait de vache. Ce pouvoir tampon augmentait avec l'extrait sec du lait reconstitué. Toutes les souches protéinase-positives ont eu un taux de croissance spécifique $\left(\mu_{\max }\right)$ et un taux d'acidification plus élevés que les variants protéinase-négative. Le nombre de bactéries et la concentration en acide lactique, après $15 \mathrm{~h}$ d'incubation, étaient également plus élevés avec les souches protéinase-positives. Pour toutes les souches, le taux d'acidification et la concentration en acide lactique après $15 \mathrm{~h}$ d'incubation étaient significativement plus élevés dans le lait de chèvre reconstitué que dans celui de vache et augmentaient avec la teneur en extrait sec des laits reconstitués. Le $\mu_{\max }$ et le nombre de bactéries viables obtenus après $15 \mathrm{~h}$ d'incubation étaient relativement proches dans les laits de chèvre et de vache reconstitués, excepté pour les souches $\mathrm{Wg} 2 \mathrm{~S}$ et $\mathrm{Wg} 2 \mathrm{~L}$. Pour ces dernières, les valeurs de $\mu_{\max }$ étaient significativement plus élevées dans le lait de chèvre, mais leur nombre après $15 \mathrm{~h}$ d'incubation était inférieur dans le lait de chèvre comparativement au lait de vache. Un découplage entre la croissance bactérienne des souches $\mathrm{Wg} 2 \mathrm{~S}$ et $\mathrm{Wg} 2 \mathrm{~L}$ et la production d'acide lactique a été observé dans le lait de chèvre. Globalement, le lait de chèvre reconstitué constitue un milieu approprié pour produire des ferments lactiques mésophiles. Cependant, pour prévenir le découplage avec certaines souches de lactocoques comme $\mathrm{Wg} 2 \mathrm{~S}$ et $\mathrm{Wg} 2 \mathrm{~L}$, la durée d'incubation à $21^{\circ} \mathrm{C}$ devrait être plus courte pour le lait de chèvre que pour le lait de vache reconstitué.

poudre de lait de chèvre / poudre de lait de vache / croissance de lactocoques / lait reconstitué / protéinase-négative

List of abbreviations: $\mathrm{Prt}^{+}$: proteinase-positive; $\mathrm{Prt}^{-}$: proteinase-negative; $\mathrm{NCN}$ : non-casein nitrogen; NPN: non-protein nitrogen; TN: total nitrogen; $\Delta \mathrm{B} / \Delta \mathrm{pH}$ : buffer index; $\mu_{\max }$ : maximum specific growth rate; LAB : lactic acid bacteria.

\section{INTRODUCTION}

Lactic acid bacteria (LAB) are widely used as starters to produce numerous fermented dairy products. The main function of these starters is the acidification of milk by the formation of lactic acid from lactose, a process that modifies the texture and flavor of dairy products. For most purposes, the ability to produce acid at a high and predictable rate is essential in cheese starters [8]. However, although the acidifying activity of different LAB has been studied worldwide in cow milk, very little scientific information is available on the growth of LAB in goat milk [2], especially with respect to reconstituted powders. The majority of the studies that have been car- ried out refer to the final acid production in goat milk. Dutta et al. [9] showed that bacterial growth and lactic acid production in goat and cow milks were similar. Casalta et al. [5] showed that the origin of the milk (cow, goat or ewe) influenced the acidification rate, which was generally higher in goat milk. Masle and Morgan [16] showed that lactic acid starter activity in goat milk was influenced by the composition of the milk, and notably by the buffering components such as proteins and minerals. Thus, improved activity of mesophilic lactic starters was observed in goat milks as a result of high protein and mineral levels. Ibrahim et al. [13] showed that after one day of incubation a cow milk culture had higher bacterial counts than goat milk culture, but that 
after three days of incubation the bacterial count of the cow milk was markedly reduced, whereas no changes were observed in the goat milk. Ibrahim et al. [13] concluded that given that the death rate was higher in cow milk cultures than in goat milk cultures, goat milk is more suitable for the growth of lactic acid starters, as well as for the manufacture of fermented dairy products. Portmann and Pierre [19] showed that the growth of a lactic acid starter was similar in cow and goat milks heated between 70 and $90{ }^{\circ} \mathrm{C}$. They recommended using LAB grown in goat milk to produce pure goat cheeses. These studies showed that mesophilic lactococci grew well in goat milk and that starters could be prepared on this substrate. However, the majority of the studies in the literature were conducted using fresh goat milk. No systematic study of the production of mesophilic starters in reconstituted goat milk has been reported. The use of reconstituted milk is strongly recommended for the production of starters [6]. Thus, there is a need for better knowledge about the growth of lactococci in reconstituted goat milk.

In Canada, the production of goat milk has increased by over $20 \%$ per year since 1995 and this is mainly linked to the production of goat cheeses [12]. Normally, to obtain a fermented goat milk product that can be marketed as a pure goat milk product, the manufacturer must prepare the starter in goat milk [1,19]. Before the starter cultures became available as frozen concentrates or as dried preparations for direct vat inoculation, they were traditionally produced and maintained by propagation in reconstituted milk powder. Today, many Canadian dairy industries still use skim milk powder to produce lactic acid starters.

Among LAB, there are proteinase-positive $\left(\mathrm{Prt}^{+}\right)$strains and proteinase-negative $\left(\mathrm{Prt}^{-}\right)$variants. As $\mathrm{Prt}^{-}$variants do not have proteinase to hydrolyze proteins, those variants stop growing in milk when the free amino acids and peptides have been consumed; in contrast, $\mathrm{Prt}^{+}$strains can continue to grow as a result of their proteolytic activity $[17,28]$. The specific growth rate of $\mathrm{Prt}^{+}$ strains and $\mathrm{Prt}^{-}$variants is apparently asso- ciated with the composition of the culture medium [26]. The composition of goat milk is different from that of cow milk [15, 27]. Casalta et al. [5] showed that acidification in reconstituted goat, cow and ewe milks after 6 hours of incubation at $30{ }^{\circ} \mathrm{C}$ was faster with $\mathrm{Prt}^{+}$strains than with $\mathrm{Prt}^{-}$variants. However, it is not known whether total solids have an influence on growth.

The objective of this study was to compare the growth and the lactic acid production of some $\mathrm{Prt}^{+}$and $\mathrm{Prt}^{-}$strains of Lactococcus lactis in reconstituted goat and cow milks at different total solids contents in order to determine whether goat milk is an appropriate medium for the production of mesophilic LAB starters.

\section{MATERIALS AND METHODS}

\subsection{Milk preparation}

The skim cow milk powder was obtained from Agropur (Granby, Quebec, Canada). The goat milk powder was produced from bulk goat milk (Nubian, LaMancha, Saaneen, Alpine and Toggenburg breeds) purchased from La Laiterie Tournevent (Drummondville, Quebec, Canada) during the summer of 2005. The goat milk was skimmed by using a centrifuge (Alfa-Laval, Type 62181 m-60/1954, Uppsala, Sweden), evaporated to $400 \mathrm{~g} \cdot \mathrm{kg}^{-1}$ of total solids by means of an APV Anhydro evaporator type JPE (APV, Goldsboro, NC, USA) and dried using a rotary spray dryer (Niro Atomizer, P6,3, modelV, Copenhagen, Denmark). The dryer inlet and outlet temperatures were 185 and $85^{\circ} \mathrm{C}$, respectively. Both milk powders were vacuum packed and stored at $4{ }^{\circ} \mathrm{C}$ prior to use.

The cow and goat milk powders were rehydrated in water at $23^{\circ} \mathrm{C}$ for a 1 -h period to obtain 3 reconstituted cow milks at 90 , 120 and $150 \mathrm{~g} \cdot \mathrm{kg}^{-1}$ dry matter and 3 reconstituted goat milks at 90,120 and $150 \mathrm{~g} \cdot \mathrm{kg}^{-1}$ total solids. All the reconstituted milks were heated at $85^{\circ} \mathrm{C}$ for $30 \mathrm{~min}$, cooled in ice at $4{ }^{\circ} \mathrm{C}$ and distributed in $14-\mathrm{mL}$ sterilized tubes. All the tubes were stored at $4{ }^{\circ} \mathrm{C}$ for $18 \mathrm{~h}$ prior to use for bacterial growth. 


\subsection{Analytical methods}

The composition of the cow and goat milk powders was determined in duplicate. Dry matter was determined by air-drying at $100{ }^{\circ} \mathrm{C}$ [3], fat content was determined using the Mojonnier extraction procedure [4] and ash was determined by heating samples at $550{ }^{\circ} \mathrm{C}$ for $16 \mathrm{~h}$ in a muffle furnace [3]. Total nitrogen (TN) and non-casein nitrogen $(\mathrm{NCN})$ were measured using the macro-Kjeldahl method [3]. The NCN was measured on the filtrate after casein precipitation at $\mathrm{pH} 4.6$, whereas non-protein nitrogen (NPN) was determined on the filtrate obtained after milk protein removal $(1: 1)$ with $240 \mathrm{~g} \cdot \mathrm{kg}^{-1}$ trichloroacetic acid solution. Casein nitrogen was obtained by means of substraction (TN-NCN). A nitrogen-to-protein conversion factor of 6.38 was applied. The relative proportion of $\alpha_{\mathrm{s} 1^{-}}$ casein, $\alpha_{\mathrm{s} 2}$-casein, $\beta$-casein and $\kappa$-casein in every powder was determined by high-performance liquid chromatography (HPLC) according to the method described by Jaubert and Martin [14]. Calcium and phosphorus were determined with an inductively coupled plasma spectrometer (model 3510 ICP Spectrometer, Applied Research Laboratories, Sunland, California, USA) according to the method described by St-Gelais et al. [24].

The buffering capacity was determined by titration with $0.36 \mathrm{~g} \mathrm{HCl} \cdot \mathrm{L}^{-1}$ until a final $\mathrm{pH}$ of 4.6 as described by Van Slyke [29]. The buffer index was calculated by using the following equation:

$$
\Delta \mathrm{B} / \Delta \mathrm{pH}=\frac{(\mathrm{mL} \text { of } \mathrm{HCI}) \times(\text { normality factor })}{(\text { volume of sample }) \times(\Delta \mathrm{pH})} .
$$

\subsection{Lactococci strains}

A $\mathrm{Prt}^{+}$strain of Lactoccocus lactis ssp. lactis CNRZ-1076 (1076), and its Prt ${ }^{-}$variant, CNRZ-1075 (1075), were obtained from the Centre de Recherches de Jouy-enJosas (Institut National de Recherche Agronomique, Domaine de Vilvert, France). Two $\mathrm{Prt}^{+}$strains of L. lactis ssp. cremoris, $\mathrm{Wg} 2 \mathrm{~S}$ and E8S, and their $\mathrm{Prt}^{-}$variants,
$\mathrm{Wg} 2 \mathrm{~L}$ and E8L, were obtained from the Netherlands Institute for Dairy Research (NIZO, Ede, the Netherlands). Each lactococcal culture was kept in reconstituted skim milk (200 $\mathrm{g} \cdot \mathrm{kg}^{-1}$ dry matter) containing $50 \mathrm{~g} \cdot \mathrm{kg}^{-1}$ sucrose and $1.7 \mathrm{~g} \cdot \mathrm{kg}^{-1}$ ascorbic acid and was stored at $-40^{\circ} \mathrm{C}$.

\subsection{Culture and bacterial growth}

Working cultures were propagated (inoculum size $100 \mathrm{~g} \cdot \mathrm{kg}^{-1}$ ) in reconstituted cow milk (120 g. $\mathrm{kg}^{-1}$ dry matter) supplemented with $2.0 \mathrm{~g} \cdot \mathrm{kg}^{-1}$ yeast extract (Difco Laboratories, Detroit, MI, USA) and sterilized at $110{ }^{\circ} \mathrm{C}$ for $10 \mathrm{~min}$; incubation was performed at $21^{\circ} \mathrm{C}$ for $15 \mathrm{~h}$. For the second transfer, growth was performed in reconstituted cow milk without yeast extract for the $\mathrm{Prt}^{+}$strains and with $2.0 \mathrm{~g} \cdot \mathrm{kg}^{-1}$ yeast extract for the $\mathrm{Prt}^{-}$variants at $30^{\circ} \mathrm{C}$ for $6 \mathrm{~h}$. The last transfer for all the strains was performed in M17 broth (Difco Laboratories, Detroit, MI, USA), which was incubated at $21^{\circ} \mathrm{C}$ for $15 \mathrm{~h}$. Active cultures were then centrifuged at $3000 \times g$ at $23{ }^{\circ} \mathrm{C}$ for $10 \mathrm{~min}$ (Centra-GP8R, International Equipment Company, Needham Heights, MA, USA). The pellet (bacteria) was diluted in a sterile saline solution $(9.0 \mathrm{~g}$ $\left.\mathrm{NaCl} \cdot \mathrm{kg}^{-1}\right)$ to obtain an optical density of $1.40(\lambda=635 \mathrm{~nm})$ using a Beckman spectrophotometer (DU Series 60 Spectrophotometer; Beckman Instruments Inc., Fullerton, CA, USA). The lactococci population in the diluted saline solution was approximately $8 \times 10^{8} \mathrm{cfu} \cdot \mathrm{mL}^{-1}$ for all the strains.

All the reconstituted milks were inoculated with each diluted saline solution to obtain approximately $2 \times 10^{7} \mathrm{cfu} \cdot \mathrm{mL}^{-1}$ and all the tubes were incubated at $21^{\circ} \mathrm{C}$ for $15 \mathrm{~h}$. This temperature is generally used by manufacturers to produce mesophilic lactic acid starters [6]. The population of the $\mathrm{Prt}^{+}$ and $\mathrm{Prt}^{-}$strains was determined after 0,3 , 6, 9, 12 and 15 h on M17 agar (Difco Laboratories, Detroit, MI, USA), which was incubated anaerobically at $30{ }^{\circ} \mathrm{C}$ for $48 \mathrm{~h}$. Milk samples were diluted in $1.0 \mathrm{~g} \cdot \mathrm{kg}^{-1}$ peptone water. However, because some lactococci grow in long chains [10], $3 \mathrm{~g}$ of 4-mm solid glass beads were added to each 
dilution bottle. To ensure disintegration of the long chains, all the dilution bottles were vigorously shaken 40 times before inoculation on M17 agar plates [25]. The $\mu_{\max }$ were calculated during exponential growth using the following equation:

$$
\ln X=\ln X_{0}+\mu_{\max } \times T
$$

where $X_{0}$ (intercept) is the biomass $\left(\mathrm{cfu} \cdot \mathrm{mL}^{-1}\right.$ ) when time $T(\mathrm{~h})=0$. The plot of $\ln X$ against time is a straight line with a slope of $\mu_{\max }$.

Titratable acidity was determined with $4.4 \mathrm{~g} \cdot \mathrm{L}^{-1} \mathrm{NaOH}$ and reported as grams of lactic acid per liter. The acidification rate for the $\mathrm{Prt}^{+}$strains was calculated using the following sigmoid equation:

$$
\Delta \mathrm{LA}=\frac{(a-d)}{\left(1+\left(\frac{t}{c}\right)^{b}\right)^{e}}+d
$$

where $\Delta \mathrm{LA}=$ lactic acid produced $\left(\mathrm{g} \cdot \mathrm{L}^{-1}\right)$, $a=$ minimum lactic acid concentration (which is 0 ), $b=$ slope coefficient, $c=$ inflection point coefficient, $d=$ maximum lactic acid concentration at infinite time, $e=$ a symmetric parameter, and $t=$ time (h). These parameters $(a, b, c, d$ and $e$ ) were obtained by curve fitting to the above model using SigmaPlot software version 8 (SPSS Inc., Chigaco, IL, USA). Equation (3) and its first and second derivatives [18] are used to determine the acidification rate at the inflection time. Because lactic acid production with the $\mathrm{Prt}^{-}$variants was linear (Fig. 2D), the acidification rate of those variants was calculated by using the following linear equation:

$$
\Delta \mathrm{LA}=a+b t
$$

where $\Delta \mathrm{LA}=$ lactic acid produced $\left(\mathrm{g} \cdot \mathrm{L}^{-1}\right)$, $a=$ concentration of lactic acid when $t=0 \mathrm{~h}$, $b=$ acidification rate, and $t=$ time (h).

\subsection{Statistical methods}

Analysis of variance according to a splitplot design was applied to determine the effects of the types of milk, the concentration of milk total solids and the different strains of L. lactis on the maximum specific growth rate $\left(\mu_{\max }\right)$, the population after
Table I. Composition of cow and goat milk powders $\left(\mathrm{g} \cdot \mathrm{kg}^{-1}\right)$.

\begin{tabular}{lrc}
\hline Constituent $^{1}$ & \multicolumn{2}{c}{ Type of powder } \\
\cline { 2 - 3 } & \multicolumn{1}{c}{ Cow } & Goat \\
\hline Dry matter & 960 & 962 \\
Total proteins & 348 & 381 \\
Casein & 270 & 273 \\
$\alpha_{\text {s1-CN }}$ & 119 & 46 \\
$\alpha_{\text {s2 }}$ CN & 18 & 51 \\
$\beta$-CN & 109 & 142 \\
$\kappa$-CN & 22 & 33 \\
Whey protein & 58 & 80 \\
$\alpha$-Lb & 19 & 22 \\
$\beta$-Lg & 37 & 55 \\
Non-protein nitrogen & 21 & 28 \\
Fat & 8 & 11 \\
Ash & 79 & 94 \\
Calcium & 12 & 15 \\
$\quad$ Phosphorus & 8 & 12 \\
Lactose & 504 & 467 \\
\hline CN
\end{tabular}

${ }_{1}^{1} \mathrm{CN}=$ casein; $\alpha-\mathrm{Lb}=\alpha$-lactalbumin; $\beta$ - $\mathrm{Lg}=\beta$ lactoglobulin.

$15 \mathrm{~h}$ of incubation, the acidification rate and the lactic acid concentration after $15 \mathrm{~h}$ of incubation. The experiment was performed in triplicate. In this design, types of milk, milk solids contents and replicates were the main plots, and strains were the subplots. These statistical analyses were performed with the general linear models procedure of SAS [22].

\section{RESULTS}

\subsection{Composition of milk powders}

The composition of goat and cow milk powders is presented in Table I. Dry matter contents were close in both types of milk powder. Total protein content was higher in goat milk powder than in cow milk powder, mostly due to the higher whey protein and NPN contents of goat milk powder. In goat 
Table II. Probability values ${ }^{1}$ for the effect of types of milk (cow and goat) and levels of solids $\left(90,120\right.$ and $\left.150 \mathrm{~g} \cdot \mathrm{kg}^{-1}\right)$ on the buffering capacity of reconstituted milks.

\begin{tabular}{lc}
\hline & Buffering capacity \\
\hline Main factors & 0.0002 \\
Milks & 0.0001 \\
Solids & \\
& \\
Interaction & 0.03 \\
Milks $\times$ Solids
\end{tabular}

1 Probability values $\leq 0.05$ are considered statistically significant.

milk powder, the concentration of fat, ashes, calcium and phosphorus was higher, whereas the lactose content was lower. The casein contents in both types of milk powder were similar, although the $\alpha_{\mathrm{s} 2}$-casein, $\beta$-casein and $\kappa$-casein contents were higher and the $\alpha_{\mathrm{s} 1}$-casein content was lower in goat milk than in cow milk. The $\alpha$-lactalbumin and $\beta$-lactoglobulin contents were also higher in the goat milk powder.

\subsection{Buffering capacity}

Table II presents the significant effects of types of milk and total solid contents on the buffering capacity of reconstituted milks. All the main factors had a significant effect on the buffering capacity, and a significant interaction between types of milk and total solid contents was also observed. Buffering capacity increased significantly with the milk total solids and was higher for goat milk, especially at 120 and $150 \mathrm{~g} \cdot \mathrm{kg}^{-1}$ total solids (Fig. 1).

\subsection{Growth, pH evolution and lactic acid production}

Table III presents the significant effects of the main factors as well as of the various significant interactions between types of milk, total solid contents and strains on $\mu_{\max }$, total lactococci population after $15 \mathrm{~h}$ of incubation, acidification rate for the $\mathrm{Prt}^{+}$ and $\mathrm{Prt}^{-}$strains and the lactic acid concentration for the $\mathrm{Prt}^{+}$and $\mathrm{Prt}^{-}$strains obtained after $15 \mathrm{~h}$ of incubation. The types of milk and strains had a significant effect on all the measured parameters. The level of solids also had a significant effect on all the parameters, with the exception of the $\mu_{\max }$. A significant interaction between strains and types of milk was observed for all the measured parameters. In addition, a significant interaction between strains and level of solids was observed for the acidification rate and the lactic acid concentration after $15 \mathrm{~h}$ of incubation for the $\mathrm{Prt}^{-}$variants. However,

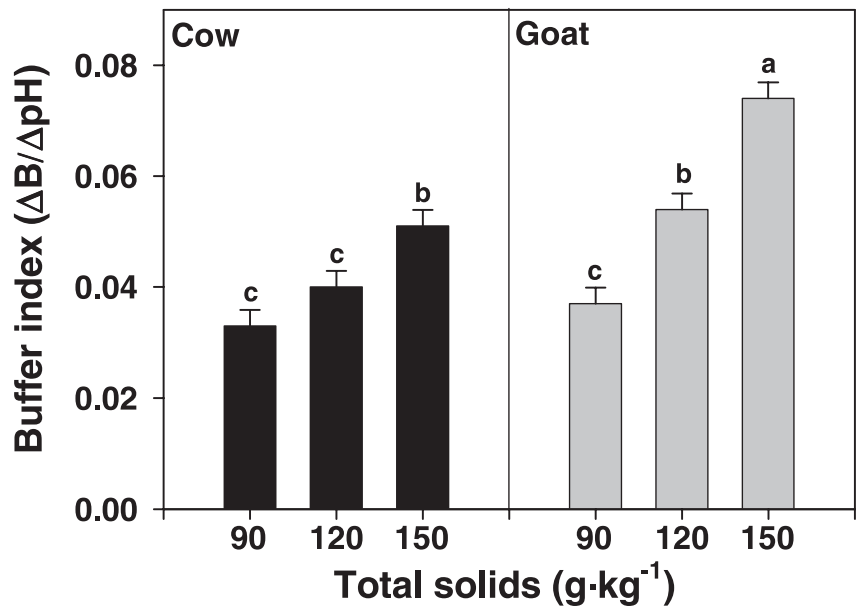

Figure 1. Buffer index of cow and goat milk reconstituted at 90,120 and $150 \mathrm{~g} \cdot \mathrm{kg}^{-1}$ total solids. 
Table III. Probability values ${ }^{1}$ for the effect of types of milk (cow and goat), levels of solids (90, 120 and $\left.150 \mathrm{~g} \cdot \mathrm{kg}^{-1}\right)$ and strains of lactococci $\left(\mathrm{Prt}^{+}\right.$and $\left.\mathrm{Prt}^{-}\right)$on different measured parameters.

\begin{tabular}{llccccc}
\hline & $\mu_{\max }$ & $\begin{array}{c}\text { Population } \\
\text { count } \\
\text { after 15 h }\end{array}$ & $\begin{array}{c}\mathrm{Prt}^{+} \\
\text {acidification } \\
\text { rate }\end{array}$ & $\begin{array}{c}\mathrm{Prt}^{-} \\
\text {acidification } \\
\text { rate }\end{array}$ & $\begin{array}{c}\mathrm{Prt}^{+} \\
\text {acid lactic } \\
\text { content } \\
\text { after 15 h }\end{array}$ & $\begin{array}{c}\text { Prt }^{-} \\
\text {acid lactic } \\
\text { content } \\
\text { after 15 h }\end{array}$ \\
\hline Main factors & & & & & & \\
Milks & 0.03 & 0.0001 & 0.0001 & 0.0001 & 0.0001 & 0.0001 \\
Solids & 0.25 & 0.0001 & 0.0001 & 0.0001 & 0.0001 & 0.0001 \\
Strains & 0.0001 & 0.0001 & 0.0001 & 0.0001 & 0.0001 & 0.0001 \\
& & & & & & \\
Interactions & & & & & & \\
Milks $\times$ Solids & 0.11 & 0.28 & 0.27 & 0.52 & 0.10 & 0.35 \\
Strains $\times$ Milks & 0.02 & 0.02 & 0.006 & 0.0001 & 0.002 & 0.01 \\
Strains $\times$ Solids & 0.49 & 0.15 & 0.44 & 0.0001 & 0.53 & 0.002 \\
Strains $\times$ Milks & 0.30 & 0.11 & 0.70 & 0.43 & 0.42 & 0.32 \\
$\times$ Solids & & & & & & \\
\hline
\end{tabular}

${ }^{1}$ Probability values $\leq 0.05$ are considered statistically significant.

no significant double interactions between the types of milk and level of solids or triple interactions between strains, types of milk and level of solids were observed for any of the measured parameters.

The growth of the $\mathrm{Prt}^{+}$and $\mathrm{Prt}^{-}$strains in reconstituted cow and goat milk powders is shown in Figure 2A. The curves correspond to the combined means of the 3 levels of solid contents. The growth of all lactococci in reconstituted cow and goat milks at 90, 120 and $150 \mathrm{~g} \cdot \mathrm{kg}^{-1}$ total solids is shown in Figure $3 \mathrm{~A}$. The curves correspond to the combined means of the $3 \mathrm{Prt}^{+}$and $3 \mathrm{Prt}^{-}$ strains. All the lactococci grew in all the reconstituted cow and goat milks. However, the growth of all the $\mathrm{Prt}^{-}$variants was slower than that of the $\mathrm{Prt}^{+}$strains (Fig. 2A). The stationary phase for the $\mathrm{Prt}^{+}$strains was reached between 9 and $12 \mathrm{~h}$, while it was reached after $6 \mathrm{~h}$ for the Prt $^{-}$variants. The lactococci population increased as the concentration of milk total solids increased (Fig. 3A).

The $\mu_{\max }$, calculated by using equation (2), and the total lactococci population after $15 \mathrm{~h}$ of incubation according to the type of milk, concentration of total solids and strain are presented in Table IV. The $\mu_{\max }$ for the $\mathrm{Prt}^{+}$strains was significantly higher than the $\mu_{\max }$ for the Prt ${ }^{-}$variants. The $\mu_{\max }$ was also higher in goat milk than in cow milk, but only for the $\mathrm{Wg} 2 \mathrm{~S}$ and $\mathrm{Wg} 2 \mathrm{~L}$ strains. For the other strains, the $\mu_{\max }$ was similar in both types of reconstituted milk. In addition, the $\mu_{\max }$ increased significantly as the total solid contents increased in the milk, but only for the 1076 and 1075 strains. For the other strains (E8S, E8L, Wg2S and $\mathrm{Wg} 2 \mathrm{~L}$ ) the $\mu_{\max }$ was similar whatever the concentration of total solids.

The populations of all the $\mathrm{Prt}^{+}$strains after $15 \mathrm{~h}$ of incubation were significantly higher than those for the $\mathrm{Prt}^{-}$variants (Tab. IV). The populations for the Wg2S and $\mathrm{Wg} 2 \mathrm{~L}$ strains were significantly lower in reconstituted goat milk than in cow milk, while the populations for the other strains were not significantly different in either type of milk. In addition, the populations increased significantly with the milk total solid contents, with the exception of the populations for the $\mathrm{Wg} 2 \mathrm{~S}$ and $\mathrm{Wg} 2 \mathrm{~L}$ strains, which stayed relatively constant. 

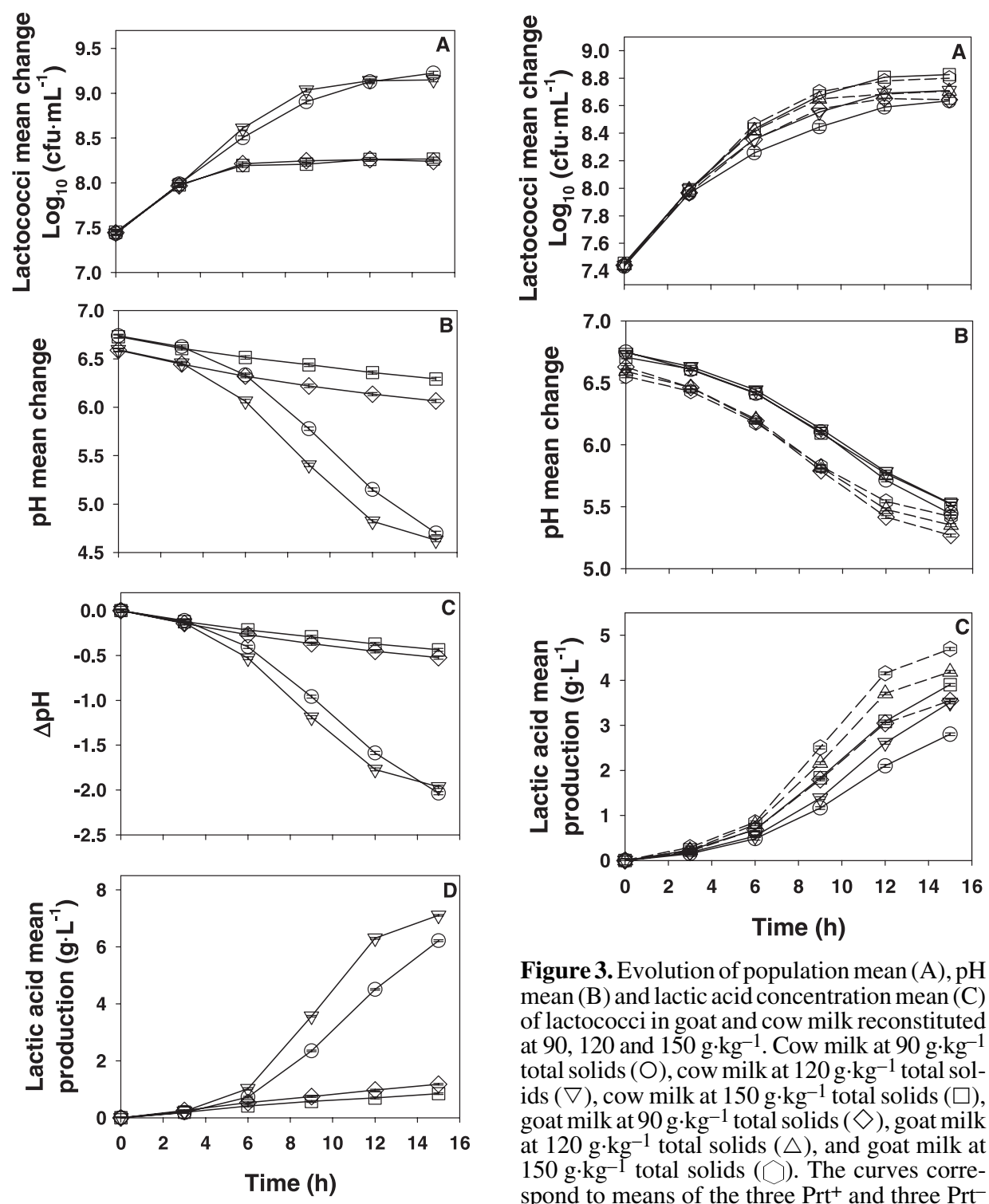

Figure 3. Evolution of population mean (A), $\mathrm{pH}$ mean (B) and lactic acid concentration mean (C) of lactococci in goat and cow milk reconstituted at 90,120 and $150 \mathrm{~g} \cdot \mathrm{kg}^{-1}$. Cow milk at $90 \mathrm{~g} \cdot \mathrm{kg}^{-1}$ total solids $(\mathrm{O})$, cow milk at $120 \mathrm{~g} \cdot \mathrm{kg}^{-1}$ total solids $(\nabla)$, cow milk at $150 \mathrm{~g} \cdot \mathrm{kg}^{-1}$ total solids $(\square)$, goat milk at $90 \mathrm{~g} \cdot \mathrm{kg}^{-1}$ total solids $(\diamond)$, goat milk at $120 \mathrm{~g} \cdot \mathrm{kg}^{-1}$ total solids $(\triangle)$, and goat milk at $150 \mathrm{~g} \cdot \mathrm{kg}^{-1}$ total solids $(\bigcirc)$. The curves correspond to means of the three $\mathrm{Prt}^{+}$and three Prt strains. Error bars represent the standard error

Figure 2. Evolution of population mean (A), $\mathrm{pH}$ mean (B), $\Delta \mathrm{pH}$ mean (C) and lactic acid concentration mean (D) of proteinase-positive $\left(\mathrm{Prt}^{+}\right)$and proteinase-negative $\left(\mathrm{Prt}^{-}\right)$strains of lactococci in rehydrated goat and cow milk powders. $\mathrm{Prt}^{+}$strains in cow milk (O), $\mathrm{Prt}^{+}$ strains in goat milk $(\nabla)$, Prt $^{-}$variants in cow milk $(\square)$, and $\operatorname{Prt}^{-}$variants in goat milk $(\diamond)$. The curves correspond to the means of the three levels of solid contents. Error bars represent the standard error of the means.

The $\mathrm{pH}$ evolution with the $\mathrm{Prt}^{+}$and $\mathrm{Prt}^{-}$ strains in reconstituted cow and goat milks is presented in Figure 2B. The curves correspond to the combined means of the 3 levels of solid contents. The $\mathrm{pH}$ evolution in reconstituted cow and goat milks at 90, 120 and $150 \mathrm{~g} \cdot \mathrm{kg}^{-1}$ total solids is presented in 
Table IV. Maximum specific growth rate means and total lactococcal population means after $15 \mathrm{~h}$ of incubation of different lactococci in reconstituted cow and goat milks.

\begin{tabular}{|c|c|c|c|c|c|c|c|}
\hline \multirow[t]{2}{*}{ Lactococci $^{1}$} & \multicolumn{3}{|c|}{ Type of milk } & \multicolumn{4}{|c|}{ Total solids $\left(\mathrm{g} \cdot \mathrm{kg}^{-1}\right)$} \\
\hline & Cow & Goat & SEM $^{2}$ & 90 & 120 & 150 & SEM \\
\hline & \multicolumn{7}{|c|}{ Maximum specific growth rate } \\
\hline E8S & $0.52^{\mathrm{a}}$ & $0.53^{\mathrm{a}}$ & 0.02 & $0.52^{\mathrm{ab}}$ & $0.54^{\mathrm{a}}$ & $0.52^{\mathrm{ab}}$ & 0.02 \\
\hline $\mathrm{Wg} 2 \mathrm{~S}$ & $0.44^{\mathrm{de}}$ & $0.51^{\mathrm{ab}}$ & 0.02 & $0.46^{\text {cde }}$ & $0.48^{\mathrm{bcd}}$ & $0.48^{\text {bcd }}$ & 0.02 \\
\hline 1076 & $0.51^{\mathrm{ab}}$ & $0.50^{\mathrm{abc}}$ & 0.02 & $0.46^{\text {cde }}$ & $0.50^{\mathrm{abc}}$ & $0.52^{\mathrm{ab}}$ & 0.02 \\
\hline E8L & $0.44 \mathrm{de}$ & $0.47 \mathrm{bcd}$ & 0.02 & $0.45^{\text {cde }}$ & $0.44 \mathrm{def}$ & 0.47 cde & 0.02 \\
\hline $\mathrm{Wg} 2 \mathrm{~L}$ & $0.37^{f}$ & $0.45^{\mathrm{cd}}$ & 0.02 & $0.43^{\text {def }}$ & $0.42^{\text {efg }}$ & $0.40^{\mathrm{fg}}$ & 0.02 \\
\hline \multirow[t]{2}{*}{1075} & $0.43^{\mathrm{de}}$ & $0.40^{\mathrm{ef}}$ & 0.02 & $0.37 \mathrm{~g}$ & $0.42^{\text {efg }}$ & 0.44 def & 0.02 \\
\hline & \multicolumn{7}{|c|}{ Lactococcal population $\left(\log _{10}\left(\mathrm{cfu} \cdot \mathrm{mL}^{-1}\right)\right)$} \\
\hline E8S & $9.13^{\mathrm{c}}$ & $9.15^{\mathrm{bc}}$ & 0.03 & $9.02^{\mathrm{f}}$ & $9.17 \mathrm{~cd}$ & $9.23^{b c}$ & 0.03 \\
\hline $\mathrm{Wg} 2 \mathrm{~S}$ & $9.21^{b}$ & $8.99 \mathrm{~d}$ & 0.03 & $9.11^{\mathrm{de}}$ & $9.13^{\mathrm{de}}$ & $9.06^{\mathrm{ef}}$ & 0.03 \\
\hline 1076 & $9.35^{\mathrm{a}}$ & $9.30^{\mathrm{a}}$ & 0.03 & $9.27^{b}$ & $9.31^{\mathrm{ab}}$ & $9.39^{\mathrm{a}}$ & 0.03 \\
\hline E8L & $8.30^{\mathrm{f}}$ & $8.31^{\mathrm{f}}$ & 0.03 & $8.21^{\mathrm{i}}$ & $8.33^{\mathrm{h}}$ & $8.38^{\mathrm{h}}$ & 0.03 \\
\hline $\mathrm{Wg} 2 \mathrm{~L}$ & $8.15 \mathrm{~g}$ & $8.04^{\mathrm{h}}$ & 0.03 & $8.05 \mathrm{j}$ & $8.12^{\mathrm{ij}}$ & $8.13^{\mathrm{ij}}$ & 0.03 \\
\hline 1075 & $8.43^{\mathrm{e}}$ & $8.37^{\mathrm{ef}}$ & 0.03 & $8.30^{\mathrm{h}}$ & $8.40^{\mathrm{gh}}$ & $8.48 \mathrm{~g}$ & 0.03 \\
\hline
\end{tabular}

${ }^{1} \mathrm{E} 8 \mathrm{~S}, \mathrm{Wg} 2 \mathrm{~S}$ and $1076=$ proteinase-positive strains; E8L, $\mathrm{Wg} 2 \mathrm{~L}$ and $1075=$ proteinase-negative variants.

2 SEM $=$ standard error of the means.

Means with different superscripts differ significantly $(P \leq 0.05)$.

Figure 3B. The curves correspond to the combined means of the $3 \mathrm{Prt}^{+}$and $3 \mathrm{Prt}^{-}$ strains. The $\mathrm{pH}$ value of reconstituted goat milk before inoculation was 6.59 , compared with 6.73 for reconstituted cow milks. During milk incubation the $\mathrm{pH}$ values for goat milk were always lower than those for cow milk. The $\mathrm{pH}$ evolution for both types of milk seemed to be relatively close. In fact, when the $\mathrm{pH}$ is expressed as delta $\mathrm{pH}$ (Fig. 2C), the curves for goat milk decreased slightly faster than those for cow milk. In addition, after $9 \mathrm{~h}$ (Fig. 3B), the $\mathrm{pH}$ decreased more slowly as the total solid contents increased in the milk, especially in goat milk. The $\mathrm{pH}$ evolution was also faster with $\mathrm{Prt}^{+}$strains than with $\mathrm{Prt}^{-}$variants (Fig. 2B).
Lactic acid production for the $\mathrm{Prt}^{+}$ and $\mathrm{Prt}^{-}$strains of lactococci in reconstituted cow and goat milks is presented in Figure 2D. The curves correspond to the combined means of the 3 levels of solid contents. Mean lactic acid production in reconstituted cow and goat milks at 90, 120 and $150 \mathrm{~g} \cdot \mathrm{kg}^{-1}$ total solids is presented in Figure 3C. The curves correspond to the combined means of the $3 \mathrm{Prt}^{+}$and $3 \mathrm{Prt}^{-}$ strains. Lactic acid production was higher with the $\mathrm{Prt}^{+}$strains than with the $\mathrm{Prt}^{-}$variants and was faster and higher in goat milk than in cow milk (Fig. 2D). In addition, the lactic acid production increased with milk total solid contents and was higher in goat milk than in cow milk (Fig. 3C). 
Table V. Acidification rate means and lactic acid concentration means after $15 \mathrm{~h}$ of incubation of different lactococci in reconstituted cow and goat milks.

\begin{tabular}{|c|c|c|c|c|c|c|c|}
\hline \multirow[t]{2}{*}{ Lactococci $^{1}$} & \multicolumn{3}{|c|}{ Type of milk } & \multicolumn{4}{|c|}{ Total solids $\left(\mathrm{g} \cdot \mathrm{kg}^{-1}\right)$} \\
\hline & Cow & Goat & SEM $^{2}$ & 90 & 120 & 150 & SEM $^{2}$ \\
\hline & \multicolumn{7}{|c|}{ Acidification rate } \\
\hline E8S & $0.92^{\mathrm{c}}$ & $1.33^{\mathrm{a}}$ & 0.06 & $0.93^{b}$ & $1.13^{\mathrm{a}}$ & $1.31^{\mathrm{a}}$ & 0.08 \\
\hline $\mathrm{Wg} 2 \mathrm{~S}$ & $0.50^{\mathrm{e}}$ & $0.72^{\mathrm{d}}$ & 0.06 & $0.51^{\mathrm{d}}$ & $0.69^{\mathrm{c}}$ & $0.64^{\mathrm{cd}}$ & 0.08 \\
\hline 1076 & $0.51^{\mathrm{e}}$ & $1.14^{\mathrm{b}}$ & 0.06 & $0.71^{\mathrm{c}}$ & $0.81^{b c}$ & $0.94^{b}$ & 0.08 \\
\hline E8L & $0.08^{\mathrm{g}}$ & $0.11^{\mathrm{f}}$ & 0.003 & $0.07^{\mathrm{g}}$ & $0.09^{\mathrm{f}}$ & $0.13^{\mathrm{e}}$ & 0.004 \\
\hline $\mathrm{Wg} 2 \mathrm{~L}$ & $0.05^{\mathrm{h}}$ & $0.06^{\mathrm{h}}$ & 0.003 & $0.05^{\mathrm{ij}}$ & $0.06^{\mathrm{gh}}$ & $0.07 \mathrm{~g}$ & 0.004 \\
\hline \multirow[t]{2}{*}{1075} & $0.04^{\mathrm{i}}$ & $0.06^{\mathrm{h}}$ & 0.003 & $0.04 \mathrm{j}$ & $0.05^{\mathrm{hi}}$ & $0.07 \mathrm{~g}$ & 0.004 \\
\hline & \multicolumn{7}{|c|}{ Lactic acid concentration $\left(\mathrm{g} \cdot \mathrm{L}^{-1}\right)$} \\
\hline E8S & $7.02^{\mathrm{b}}$ & $7.93^{\mathrm{a}}$ & 0.14 & $6.22^{\mathrm{de}}$ & $7.59^{\mathrm{b}}$ & $8.61^{\mathrm{a}}$ & 0.23 \\
\hline $\mathrm{Wg} 2 \mathrm{~S}$ & $6.46^{\mathrm{c}}$ & $6.82^{\mathrm{b}}$ & 0.14 & $5.52^{\mathrm{fg}}$ & $6.77 \mathrm{~cd}$ & $7.70^{\mathrm{b}}$ & 0.23 \\
\hline 1076 & $5.30^{\mathrm{d}}$ & $7.05^{\mathrm{b}}$ & 0.14 & $5.15 \mathrm{~g}$ & $6.00^{\mathrm{ef}}$ & $7.36^{\mathrm{bc}}$ & 0.23 \\
\hline E8L & $1.15^{\mathrm{f}}$ & $1.55^{\mathrm{e}}$ & 0.04 & $1.02^{\mathrm{j}}$ & $1.24^{\mathrm{i}}$ & $1.78^{\mathrm{h}}$ & 0.05 \\
\hline $\mathrm{Wg} 2 \mathrm{~L}$ & $0.89^{\mathrm{h}}$ & $1.05^{\mathrm{fg}}$ & 0.04 & $0.76^{1}$ & $0.94 \mathrm{jk}$ & $1.21^{\mathrm{i}}$ & 0.05 \\
\hline 1075 & $0.64^{\mathrm{i}}$ & $0.99 \mathrm{gh}$ & 0.04 & $0.63^{\mathrm{m}}$ & $0.81^{\mathrm{kl}}$ & $1.00 \mathrm{j}$ & 0.05 \\
\hline
\end{tabular}

${ }^{1} \mathrm{E} 8 \mathrm{~S}, \mathrm{Wg} 2 \mathrm{~S}$ and 1076 = proteinase-positive strains; E8L, Wg2L and $1075=$ proteinase-negative variants.

$2 \mathrm{SEM}=$ standard error of the means.

Means with different superscripts differ significantly $(P \leq 0.05)$.

Table $\mathrm{V}$ presents the acidification rates and the lactic acid concentrations after $15 \mathrm{~h}$ of incubation calculated using equation (3) for the $\mathrm{Prt}^{+}$strains and equation (4) for the $\mathrm{Prt}^{-}$variants, allowing for comparison of the effects of the type of milk, concentration of total solids and strain. The acidification rate was higher for the $\mathrm{Prt}^{+}$strains than for the $\mathrm{Prt}^{-}$variants and was significantly higher in goat milk than in cow milk. In addition, the acidification rate increased significantly with the milk total solid contents, especially for the $\mathrm{Prt}^{+}$strains. The E8S strain had the best acidification rate among the $\mathrm{Prt}^{+}$strains, and E8L had the best acidification rate among the $\mathrm{Prt}^{-}$variants. Lactic acid production after $15 \mathrm{~h}$ of incubation was significantly lower for the $\mathrm{Prt}^{-}$var- iants than for the $\mathrm{Prt}^{+}$strains (Tab. V) and was significantly higher in goat milk than in cow milks. In addition, for all the lactococcal strains, the lactic acid concentration after $15 \mathrm{~h}$ increased significantly with the milk total solid contents. The highest contents were obtained with E8S for the $\mathrm{Prt}^{+}$ strains and E8L for the $\mathrm{Prt}^{-}$variants.

The behavior of the $\mathrm{Wg} 2 \mathrm{~S}$ strain and its variant was different comparatively to the other $\mathrm{Prt}^{+}$and $\mathrm{Prt}^{-}$strains. To demonstrate it, the population and the lactic acid concentration obtained for the E8S and $\mathrm{Wg} 2 \mathrm{~S}$ strains in reconstituted cow and goat milks at 90,120 and $150 \mathrm{~g} \cdot \mathrm{kg}^{-1}$ total solids after $15 \mathrm{~h}$ of incubation are presented in Figure 4. Similar comparative observations could be done between $\mathrm{Wg} 2 \mathrm{~S}$ or $\mathrm{Wg} 2 \mathrm{~L}$ and the other 

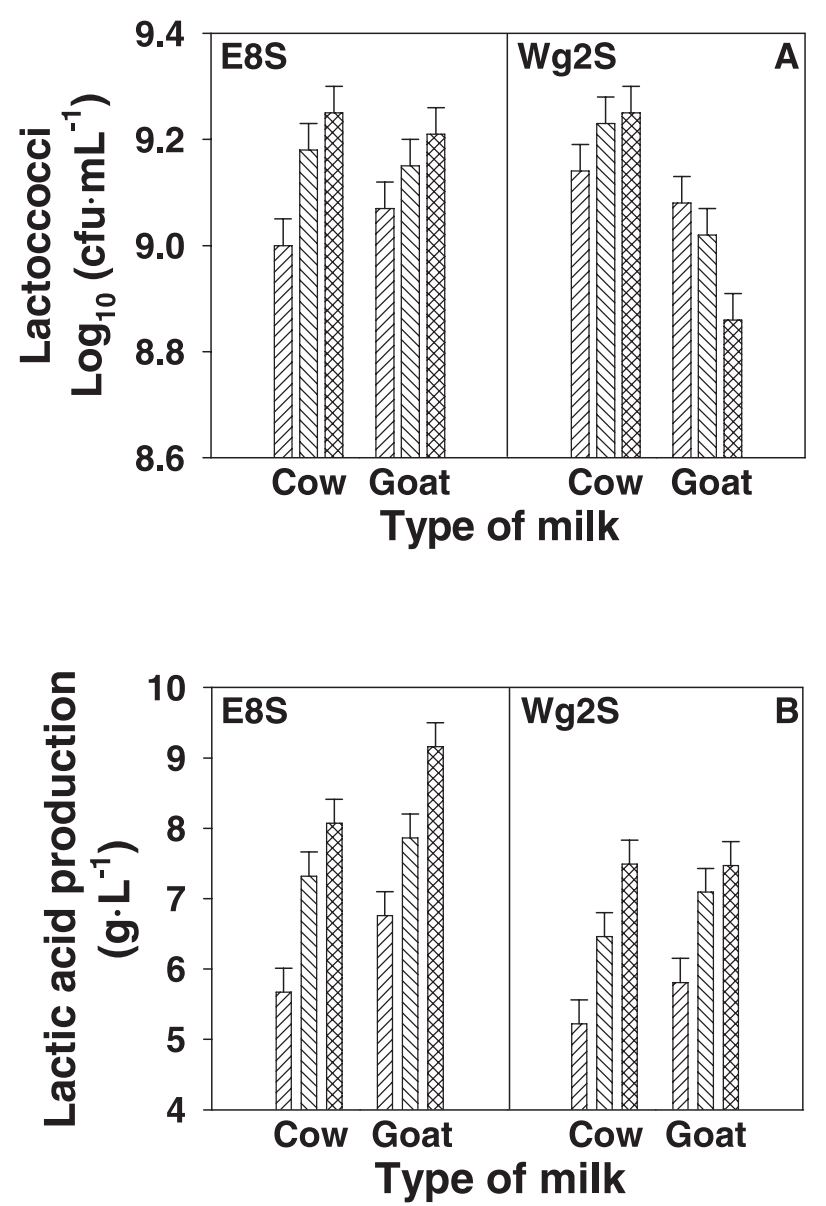

Figure 4. Lactococci count (A) and lactic acid production (B) after $15 \mathrm{~h}$ of incubation of the E8S and Wg2S strains in reconstituted cow and goat milks at 90 (ZZZZ), 120 (WIIV) and 150 (\$8又) $\mathrm{g} \cdot \mathrm{kg}^{-1}$ total solids. Error bars represent the standard error of the means.

strains (data not shown). The population of the E8S strain increased with the level of total solids in reconstituted cow and goat milks. The bacterial count of the $\mathrm{Wg} 2 \mathrm{~S}$ strain also increased with the level of total solids, but only in reconstituted cow milk. In reconstituted goat milk, the population of the $\mathrm{Wg} 2 \mathrm{~S}$ decreased with the level of total solids. However, for the E8S and $\mathrm{Wg} 2 \mathrm{~S}$ strains the lactic acid concentration increased with the level of total solids in reconstituted cow and goat milks.

\section{DISCUSSION}

In this study, the total proteins, whey protein, NPN, calcium and phosphorus contents were higher in goat milk powder than in cow milk powder. These results were similar to those obtained by Ibrahim et al. [13]. The composition of the milk can affect the buffering capacity, which increases with the total solids [21, 25, 27]. Our results confirm the literature in this respect. The buffer index of reconstituted 
milks increased with the milk total solid contents and was higher for goat milk than for cow milk. These results seem to differ from those obtained by Casalta et al. [5], who reported that goat milk had a lower buffering capacity than cow milk because of the low casein and mineral contents in goat milk. However, the composition of goat milk depends on the breed of goat [27]. In Canada, there are five goat breeds, and some of them produce milk with buffering capacities similar to or higher than cow milk [27]. In this study, the goat milk powder was obtained from bulk milk (five goat breeds). Srilaorkul et al. [23] determined that the contribution of casein, whey protein and salts to the total buffer system intensity of cow milk is $36.0,5.0$ and $59.0 \%$, respectively. Therefore, even though the casein contents between cow and goat milk powders were close, the fact that the whey protein and mineral contents, and particularly the phosphorus and calcium contents, were higher in goat milk powder than in cow milk powder could explain the higher buffering capacity of reconstituted goat milk at identical total non-fat solid contents.

Among lactococci, there are proteolytic strains and nonproteolytic variants. In this study, the $\mathrm{Prt}^{+}$strains (E8S, Wg2S and 1076) grew well in reconstituted cow and goat milks and stopped multiplying after $12 \mathrm{~h}$ of incubation, while the $\mathrm{Prt}^{-}$variants $(\mathrm{E} 8 \mathrm{~L}$, Wg2L and 1075) did not grow very well, and their viable counts stopped increasing after $6 \mathrm{~h}$. These results indicate that, in both types of reconstituted milk, the $\mathrm{Prt}^{-}$variants probably stopped growing when the free amino acids and peptides had been consumed, whereas the proteolytic activity allowed the $\mathrm{Prt}^{+}$growth to continue. The lactic acid production and the acidification rate were also higher for the $\mathrm{Prt}^{+}$strains than for the $\mathrm{Prt}^{-}$variants. These results obtained with reconstituted cow and goat milks are in agreement with those obtained by St-Gelais et al. [25], who found that the Prt $^{-}$variants E8L, Wg2L and 1075 did not grow very well in reconstituted cow milk, because these nonproteolytic strains could not hydrolyze proteins. Casalta et al. [5] observed that the $\mathrm{Prt}^{-}$variants they used could acidify goat milk to a $\mathrm{pH}$ of 5.5 after
$9 \mathrm{~h}$ of incubation, whereas cow milk was not acidified. Their results are different from those obtained in this study. The E8L, $\mathrm{Wg} 2 \mathrm{~L}$ and 1075 variants slightly acidified the reconstituted goat and cow milks. The $\mathrm{pH}$ value obtained after $15 \mathrm{~h}$ of incubation with those variants was above 6.0. These discrepancies could be due to the types of strains used to acidify the milks, to the varying buffering power of goat milk and to the treatment used to heat reconstituted milks. Casalta et al. [5] isolated their $\mathrm{Prt}^{-}$variants from goat cheese; those variants were potentially more adapted to growth in goat milk than the variants used in this study. In addition, they heated their reconstituted milks at $63{ }^{\circ} \mathrm{C}$ for $30 \mathrm{~min}$ instead of $85^{\circ} \mathrm{C}$ for $30 \mathrm{~min}$ in this study. Chavarri et al. [7] showed that the heat treatment used to heat milk can modify the lactic acid production by mesophilic bacteria.

The composition and the buffering capacity of milk can affect the growth and acidification rate of lactic acid starters $[5,9$, 13, 16, 25]. Masle and Morgan [16] showed that the acidification capacity of lactic acid starters in goat milk was influenced by variations in the composition of the milk, mainly the mineral and protein contents. The results obtained in this study confirm this observation. Even though the $\mu_{\max }$ were similar when the total solids in reconstituted milks increased, the acidification rate and lactic acid concentration measured for the $\mathrm{Prt}^{+}$and $\mathrm{Prt}^{-}$strains after $15 \mathrm{~h}$ of incubation increased with the milk total solid contents and with the buffering capacity of the milk. Moreover, the $\mathrm{pH}$ fall was slower in reconstituted milks (and in goat milk especially) at $150 \mathrm{~g} \cdot \mathrm{kg}^{-1}$ total solids than in reconstituted milks at $90 \mathrm{~g} \cdot \mathrm{kg}^{-1}$, even though the lactic acid concentration was higher in reconstituted milks (and in goat milks especially) at $150 \mathrm{~g} \cdot \mathrm{kg}^{-1}$.

Normally, the high buffering capacity of milk can act as a protective mechanism for the bacteria [16, 21]. In this study, however, the bacterial growth in reconstituted goat milk slowed down after $9 \mathrm{~h}$ of fermentation as compared with cow milk, especially at 90 and $120 \mathrm{~g} \cdot \mathrm{kg}^{-1}$ total solids, even though the buffer index was higher in the goat milk. This observation was mainly due to the 
$\mathrm{Wg} 2 \mathrm{~S}$ and $\mathrm{Wg} 2 \mathrm{~L}$ strains, which had lower viable counts after $15 \mathrm{~h}$ of incubation in goat milk than in cow milk, when compared with the other strains. Ibrahim et al. [13] observed with their lactococcal strains that cow milk allowed a higher bacterial count than goat milk after one day of incubation. After 3 days of incubation, however, the bacterial count in cow milk was reduced, and no change was observed in goat milk. These observations by Ibrahim et al. [13] were slightly different from those obtained in this study and seem to have been dependent on the types of starters used to inoculate the milk. The populations of the E8S, E8L, 1076 and 1075 strains after $15 \mathrm{~h}$ of incubation were not significantly different in reconstituted goat and cow milks, but the bacterial count for the $\mathrm{Wg} 2 \mathrm{~S}$ and $\mathrm{Wg} 2 \mathrm{~L}$ strains was significantly lower in goat milk and decreased with the level of total solids. So, an uncoupling was observed with the strains $\mathrm{Wg} 2 \mathrm{~S}$ and $\mathrm{Wg} 2 \mathrm{~L}$ in reconstituted goat milks. These strains stopped growing but the lactic acid production continued. In general, uncoupling is not desired during the production of mesophilic lactic acid starter, because the lactic acid accumulation in milk could affect the activities of bacteria (over-ripeness) $[11,20]$. The incubation of the Wg2S and $\mathrm{Wg} 2 \mathrm{~L}$ strains should be shorter in reconstituted goat milk to prevent an uncoupling and over-ripeness [20].

\section{CONCLUSION}

The results presented in this study reveal that reconstituted goat milk is an appropriate medium for the production of mesophilic lactic acid bacteria starters. In general, the performance of lactic acid starter strains in reconstituted goat milk seems to be similar to the performance in fresh goat milk that has been reported in the literature. The higher buffering capacity observed in reconstituted goat milk allowed us to obtain a better bacterial growth and lactic acid production than in reconstituted cow milk with the exception of the $\mathrm{Wg} 2 \mathrm{~S}$ and $\mathrm{Wg} 2 \mathrm{~L}$ strains. For these strains, an uncoupling was observed in goat milk. To prevent an uncoupling and an over-ripeness with some strains, like the $\mathrm{Wg} 2 \mathrm{~S}$ and $\mathrm{Wg} 2 \mathrm{~L}$ strains, incubation at $21^{\circ} \mathrm{C}$ could therefore be shorter in reconstituted goat milk than in reconstituted cow milk. Further investigation is required to determine the effect of the origin of the milk on the subsequent specific activity of lactococci in the manufacturing of fresh goat cheese.

Acknowledgments: The authors thank Gaétan Bélanger and Caroline Lapointe for their technical assistance. The authors also extend their appreciation to Claude P. Champagne for his review of this manuscript.

\section{REFERENCES}

[1] Abrahamsen R.K., Rysstad G., Fermentation of goats' milk with yogurt starter bacteria: A review, Cult. Dairy Prod. J. 26 (1991) 20-26.

[2] Alonso-Calleja C., Carballo J., Capita R., Bernardo A., Gracia-Lopez M.L., Comparison of the acidifying activity of Lactococcus lactis subsp. lactis strains isolated from goat's milk and Valdeteja cheese, Letters Appl. Microbiol. 34 (2002) 134-138.

[3] AOAC, Dairy Products, Official Methods of Analysis, Vol II, Chapter 33, 16th edn. Association of Official Analytical Chemist International, Arlington, VA, 1995.

[4] Atherton H.V., Newlander J.A., Tests for fat: Babcock, Gerber, and Mojonnier, in: Chemistry and testing of dairy products, 4th edn., Avi Publishing Co, Inc., Westport, CT, 1977, p. 71.

[5] Casalta E., Vassal Y., Desmazeaud M.J., Casabianca R., Comparaison de l'activité acidifiante de souches de Lactococcus lactis isolées de lait et de fromage de Corse, Lebensm. Wiss. Technol. 28 (1995) 291-299.

[6] Champagne C.P., Audet P., Préparation des ferments en usine, in: La Fondation des Gouverneurs and Edisem (Ed.), Production de ferments lactiques dans l'industrie laitière, Saint-Hyacinthe, Québec, Canada, 1998, pp. 117-151.

[7] Chavarri F.J., Numez J.A., Numez M., Behaviour of Streptococcus lactis in heat treated $\left(80^{\circ} \mathrm{C}\right.$ for $\left.30 \mathrm{~min}\right)$ or sterilised cow's or ewe's milk, J. Dairy Res. 50 (1983) 357-363.

[8] Cogan T.M., Hill C., Cheese starter cultures, in: Fox P.F. (Ed.), Cheese: chemistry, physics and microbiology, Chapman and Hall, London, UK, 1993, pp. 193-255. 
[9] Dutta S.M., Kuila R.K., Ranganathan B., Laxminarayana H., A comparative study of the activity of starter cultures in different types of milk, Milchwissenschaft 26 (1971) 158-161.

[10] Emmons D.B., Elliot J.A., Beckett D.C. Effect of lactic streptococcal agglutinins in milk on curd formation and manufacture of cottage cheese, J. Dairy Sci. 49 (1966) 13571366.

[11] Harvey R.J., Damage to Streptococcus lactis resulting from growth at low $\mathrm{pH}, \mathrm{J}$. Bacteriol. 90 (1965) 1330-1336.

[12] Ianni R., L'industrie de la chèvre laitière. Un portrait canadien, Agriculture and Agro Food Canada, Ottawa, Canada, 2002, pp. 1-16.

[13] Ibrahim E.M., Movran M.A., Hanafy N.E., Growth and biochemical behaviour of some lactic acid starters in cow's and goat's milk, Assiut J. Agric. Sci. 21 (1990) 205-219.

[14] Jaubert A., Martin P., Reverse-phase HPLC analysis of goat caseins; identification of $\alpha_{\mathrm{s} 1}$ and $\alpha_{\mathrm{s} 2}$ genetic variants, Lait 72 (1992) $235-$ 247.

[15] Jenness R., Composition and characteristics of goat milk: review 1968-1979, J. Dairy Sci. 63 (1980) 1605-1630.

[16] Masle I., Morgan F., Compositional factors involved in the variable acidification capacity of goat milk by lactic starters, Lait 81 (2001) 561-569.

[17] Otto R., de Vos W.M., Gavrieli J., Plasmid DNA in Streptococcus cremoris Wg2: Influence of $\mathrm{pH}$ on selection in chemostats of a variant lacking a protease plasmid, Appl. Environ. Microbiol. 43 (1982) 1272-1277.

[18] Pandey P.K., Ramaswamy H.S., St-Gelais D., Effect of high pressure processing on rennet coagulation properties of milk, Innov. Food Sci. Emerging Technol. 4 (2003) 245256.

[19] Portmann A., Pierre A., Culture de ferments lactiques dans le lait de chèvre comparaison avec le lait de vache, Revue Laitière Française 312 (1973) 629-637.

[20] Ross G.D., Observation on the effect of inoculum $\mathrm{pH}$ on the growth and acid production of lactic streptococci in milk, Aust. J. Dairy Technol. (1980) 147-149.

[21] Salaun F., Mietton B., Gaucheron F., Buffering capacity of dairy products, Int. Dairy J. 15 (2005) 95-109.

[22] SAS ${ }^{\circledR}$ User's Guide: Statistics, Version 8.2 edition. SAS Inst., Inc., Cary, NC, 1999.

[23] Srilaorkul S., Ozimek L., Wolfe F., Dziuba J., The effect of ultrafiltration on physicochemical properties of retentate, Can. Inst. Food Sci. technol. J. 22 (1989) 56-62.

[24] St-Gelais D., Haché S., Gros-Louis M., Combined effects of temperature, acidification, and diafiltration on composition of skim milk retentate and permeate, J. Dairy Sci. 75 (1992) 1167-1172.

[25] St-Gelais D., Roy D., Haché S., Growth and activities of Lactococcus lactis in milk enriched with low mineral retentate powders, J. Dairy Sci. 75 (1992) 2344-2352.

[26] St-Gelais D., Roy D., Haché S., Desjardins M.L., Gauthier S.F., Growth of nonproteolytic lactococcus lactis in culture medium supplemented with different casein hydrolyzates, J. Dairy Sci. 76 (1993) 3327-3337.

[27] St-Gelais D., Turcot S., Ould Baba Ali A., Chemical composition and properties of milk from five goat breeds, Milchwissenschaft 60 (2005) 140-143.

[28] Thomas T.D., Pritchard G.G., Proteolytic enzymes of dairy starter cultures, FEMS Microbiol. Rev. 46 (1987) 245-268.

[29] Van Slyke D.D., On the measurement of buffer values and on the relationship of buffer value to the dissociation constant of the buffer and concentration and reaction of the buffer solution, J. Biol. Chem. 52 (1922) 525-570. 